\title{
UNDISAN TOURISM VILLAGE IN BANGLI EAST OF BALI, IS A GREEN TOURISM WHERE THE TOURISTS CAN COOK A BALINESE CULINAIR TO MAINTAIN SUSTAINABLE TOURISM
}

\author{
I Wayan Pugra. \\ Polytechnic State of Bali \\ iketutredjasa@yahoo.com
}

\begin{abstract}
Nowadays the Balinese culinair is getting famous in all over Bali which are consumed by Balinese Tourists

Balinese food is available in local restaurant and international restaurant too in Bali.

Miss Rebecca Gilling who found the Denpasar Moon song, about four years ago was loving Jukut Ares (vegetable, is made from young banana tree).

Balinese food are available in big event such as in seminar, in wedding ceremony, birthday party and in international event.

Nowadays many tourists want to taste a different food to prevent boaring but want to experiencing a unique taste of Balinese cuisines.

Mr. Patrice, an owner of a travel agent in Franch has a smart idea to bring his tourist to visit the Undisan Tourism Village, in Bangli, in east part of Bali, to enjoy the beautiful panorama of Bali, while learning the local culture of Bali. Here in Undisan Tourism Village, the tourist can practice cooking Balinese traditional food, one among them is Sate Lilit.

This activity is the best way and the best idea to apply The Green Tourism to maintain the sustainable tourism, especially in Bali.
\end{abstract}

\section{INTRODUCTION}

According to an international travel magazine, it was said that Bali was the best world destination country. The incoming tourist who come to Bali from year to year is always increasing. The Indonesian government expecting this year in 2016, the six millions tourist will be coming to Indonesia.

In order to anticipating guest boaring in visiting Indonesia, a travel agent in French which is belonged to Mr. Patrice, creating a new smart idea, to bring his French tourist to undisan Tourism Village to learn cooking a Balinese cuisine, one among them is Sate Lilit, which is directly done by the tourist themselves. Some guides are guiding them to mix spices, to make the Luluh Sate Lilit by Numbuk the meat and spices by Alu in a Lesung (container) until the mixed meat is ready to be Lilit (processed).

The cooking place is a little bit unique. To produce the Sate Lilit is not in a common kitchen, but in a simple hut in the rice field. 
The owner of a travel agent in French, Mr. Patrice said that he was interested in visiting Bali because Bali was said to be the best world destination country, has rich of cultures, beautiful tourist attractions, their populations are so friendly.

While Mr. Kahal. A guide who assist his member to make Sate Lilit, said that his member were interested in learning to cook Balinese food, especially making Sate Lilit which was producing in Undisan Tourism Village, made them felt anthusiastic.

All tourist of his group, were not given theory only, but given practice directly by themselves to cook Balinese food especially to making Sate Lilit.

In the future, Mr. Patrice the owner of Travel Agent in French has an intention to enter The Undisan Tourism Village into the list of his itinerary which will be promoted in French.

\section{RESEARCH METHODOLOGY}

This research was using tourism sociology. By using the tourism sociology, the researcher will be able to determine the right object which will be searched.

In this research, the data came from premier data and secondaire one. Technical research was using observation and depth interview and documentations.

Most data were gained from those informants who knows well about this research aims, such as the tourist as the owner of the travel agent as well and also the tour guides who assist the group member.

The analyze of this research was using descriptive qualitative which means to explaining in detail the data which has been collected, then analyzed it as a scientific knowledge and finally to be exposed to the public.

\section{RESULT AND DISSCUSSION}

In Undisan Tourism Village, the tourist can learn Balinese culinair. In Bangli, eastern part of Bali, there are many tourism Villages which are interesting to be visited. One among those, is Undisan Tourism Village, in Tembuku Region. Undisan Village has a beautiful panorama, scenery, terraces, silver work and leraning local culture, one among those, is learning to make Balinese traditional food, it is Sate Lilit. 


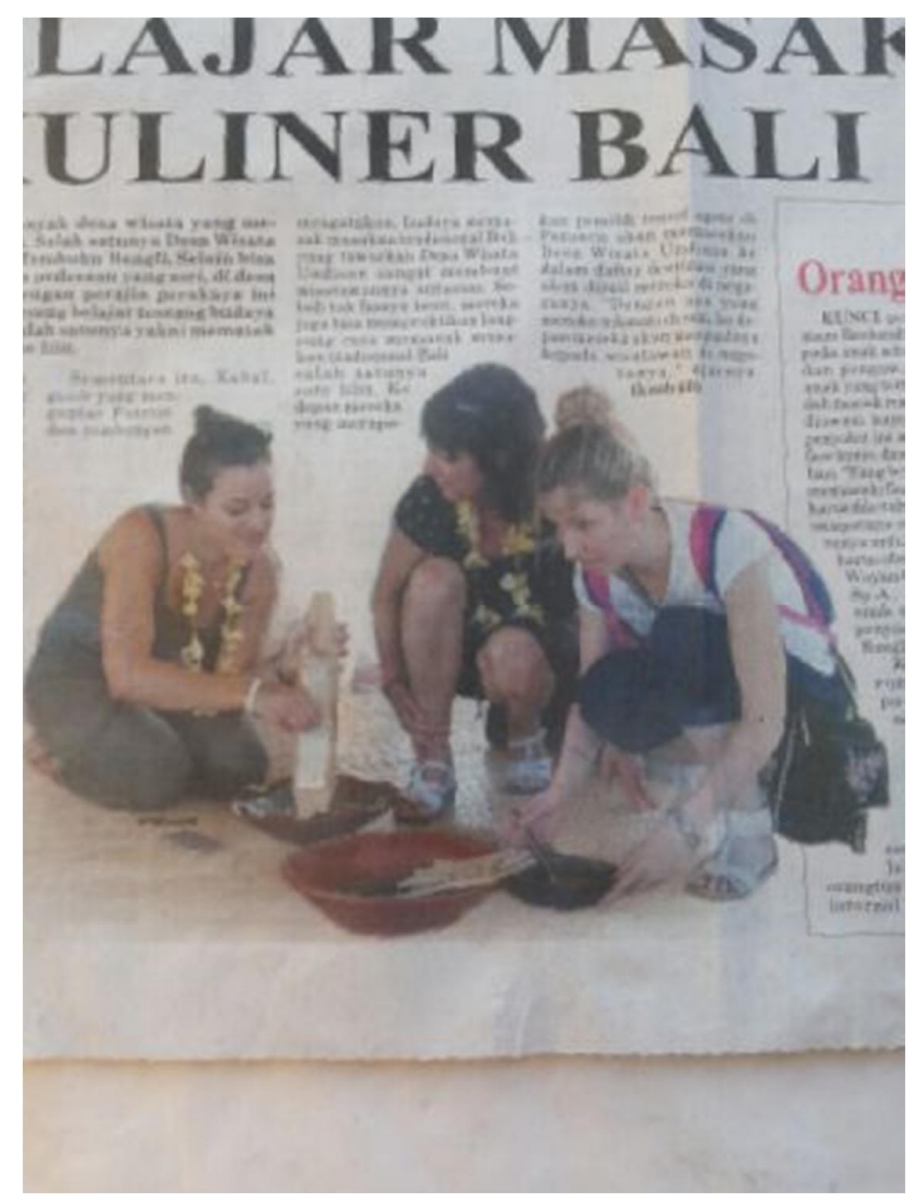

As what has been done by French tourist one week ago in Undisan Tourism Village, the tourists are taught theory of cooking and they practiced it directly by themselves to make Sate Lilit.

The tour guides as the instructor, assisting the tourist to make the Sate Lilit, starting from mixing the spices, mixing the pork with spice by Numbuk in the Lesung (container) with Alu (big stick) until ready to be Lilit.

The location of producing the Sate Lilit wasn't in common kitchen, but in a simple hut in the rice field.

One of the group member who is as the owmner of Travel Agent in French as well, Mr. Patrice said that Bali is famous as the best world destination country. Mr. Patrice said in frankly speaking, that he was interested in visiting The Undisan Tourism Village because the tourist can see beautiful panoramas, terracing rice field and the local people there were very friendly.

Mr. Kahal, a tour guide of that French group said that cooking culture of Balinese culinair which is taught to the tourists in Undisan Tourism Village can make his group member became anthusiastic.

Most tourist expressed their satisfaction after having theory and direct practice in producing the Sate Lilit completely from beginning until finished, ready to eat as their light luch. 


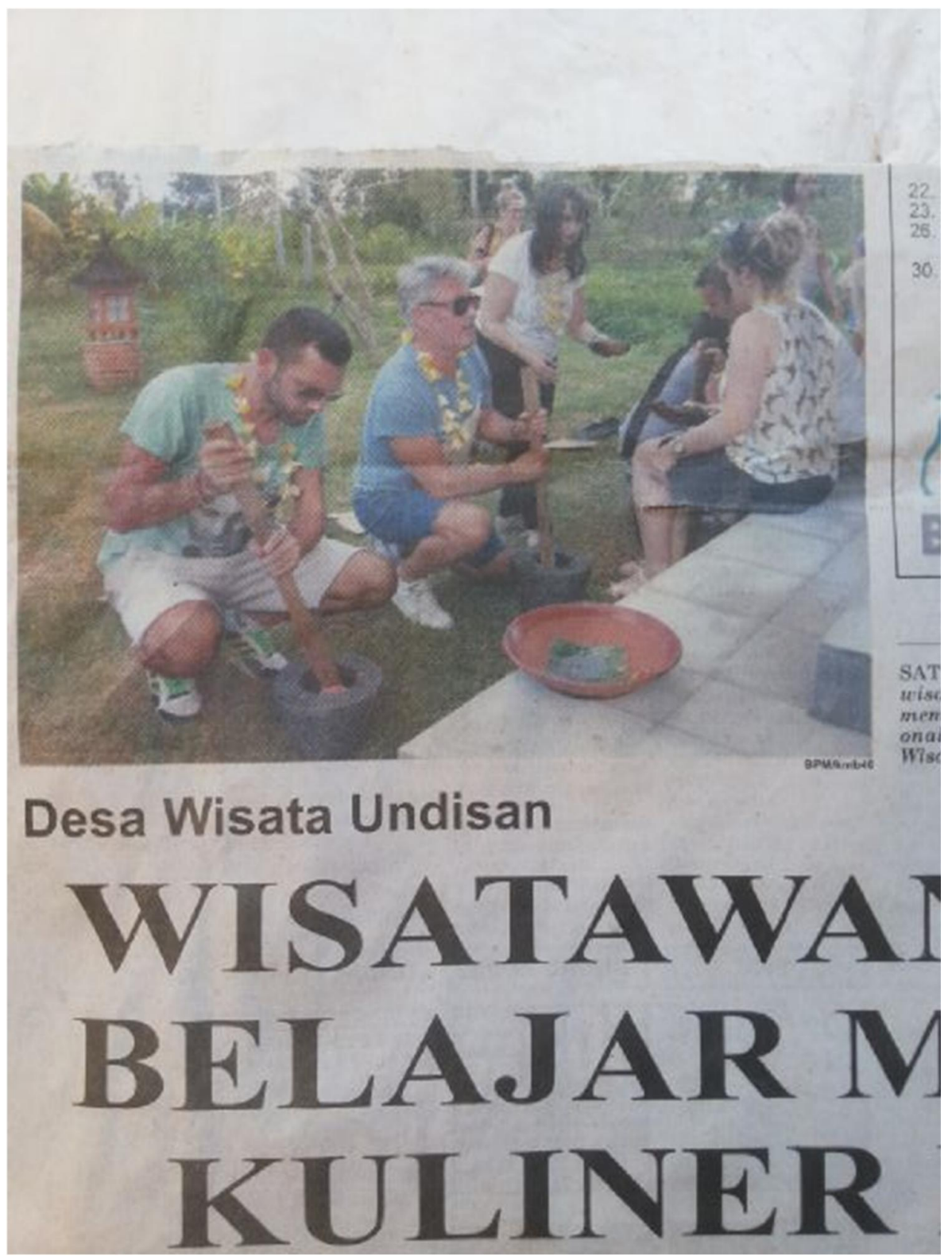

In the future, Mr. Patrice, the owner of Travel Agent in French, to plan the Undisan Tourism Village will be entered in the tour itinerary which is promoted in his Country.

His satisfaction after experiencing a memorable experience there in Undisan Tourism Village, he decide to bring more tourists there to Undisan Tourism Village every three months.

As we know that culinair has an important role for human being, because the culinair it self can't be separated from culture, social and economy.

Since a long-long time ago, the food function was as the basic of human need and then developing into ritual needs.

The food is garnished and decorated beautifully before eaten and is offered to the Supreme God before eaten by human being. 
The Balinese cuisines are always developed every time, started since Balinese King era in such a long time ago and nowadays the Balinese cuisines are available in national and international restaurant in all over Bali.

Balinese culinair is so sufficient to be developed as a creative industry because Bali is the best of the world destination country which has many varieties of region cultures including the Balinese cilinairs.

Balinese culinair has a good prospect in the future :

According to the tourist statements when interview process, said that to enjoy the special Balinese cuisine will be able to experiencing a special satisfaction.

Further, the member of that tour group said that practicing to make the Sate Lilit was as an Unforgetable and Memorable activity they experienced in Undisan Tourism Village.

\section{CONCLUSSION AND SUGGESTIONS}

\section{CONCLUSSION}

Nowadays the Balinese culinair is getting famous in all over Bali which are consumed by Balinese and visitors from overseas.

Balinese culinair are available in national restaurant and also available in international restaurant in Bali.

There are many tourism villages spread out in Bangli regency, in the east part of Bali, especially in Tembuku Region, but Undisan Village has a highly awareness of Sadar Wisata. Here, in Undisan Tourism Village, the visitors can learn to cook Balinese culinair, especially making Sate Lilit.

For the visitors aren't given cooking theory only, but they are given a chance to do directly the whole processing, starting from making spice, making the Luluh Sate by Numbuk the pork mixed with spices until ready to be Lilit.

According to the interview process to the visitors, most of them gave a good response and said that those activities they did was so interesting, memorable and unforgettable experience they got.

One of the group member and as the owner of Travel Agent in French as well, Mr. Petrice said that this good activities will be entered into his itinerary list, which will be promoted in French.

\section{SUGGESTIONS}

After telling much about Undisan Tourism Village where tourists can learn to cook Balinese culinair, in this good opportunity, I am as a researcher would like to express my suggestions such as follows :

Since Bali was stated by international travel magazine some months ago that Bali was the best world tourism destination country, so that Balinese cuisine must be high quality and hygiene.

The Balinese cuisine is so sufficient to be survived and to be offered to the six million tourists who will come here visiting Indonesia this year in 2016.

The secret of how to make various Balinese cuisines should be taught to young generation of Balinese and also to the foreigners as an advertisement, not just in local Bali only but must be spread out in all over the world widely. 
The community in Undisan Tourism Village must be always aware and understand enough about "Sadar Wisata" to invite six millions tourists who will come to Indonesia this year, 2016.

It is because of the Balinese culinair plays an important role in green tourism to maintain sustainable tourism, so that the Bali culinair should be advertised widely nationally and internationally too.

\section{REFERENCES}

Anggoro, Yudo dan Handayati yunita, 2012, Pemanfaatan Kreatifitas dan Inovasi Dalam Meningkatkan Kompetitifnes Indonesia Melalui Industri Kreatif, Dalam Stategic Management, Jakarta : The Ary Suta Center.

Anthony M. Rey, Ferdinan Wieland, 1998, Managing Service in Food and Beverage Operations, Educational Institute of The American Hotel \& Motel Association, America.

Ardika, I Wayan, (2003), Pariwisata Budaya Berkelanjutan, Denpasar : Program Studi Magister Kajian Pariwisata.

Bulletin Bendega Restaurant, 2015 and 2016.

Graham Brown, Karon Hepner, 1996, The Waiter's Hand Book, Victoria, Australia.

Guswai, 2015, Outstanding Service, Percetakan Gramedia.

Harris, Rob, et al (2002), Sustainable Tourism A Global Perspective, Oxford ; Elsevier Ltd.

Mertayasa, I Gede Agus, Food and Beverage Service Operational, Job Preparation, 2012, Penerbit : CV Andi Offset, Yogyakarta.

Mill, Robert C, 2000, Tourism The International Business (Edisi Bahasa Indonesia), Jakarta : PT. Raja Grafisindo Persada.

Moscardo, Gianna (2003), Interpretation and Sustainable Tourism : Functions, Examples, and Principle (Journal of Tourism Stidies Vol 14, No. 1, May 2003).

Mulyono, Mauted, 2010, Menggerakkan Ekonomi Kreatif, Antara Tuntutan dan Kebutuhan, Jakarta : Rajagrafindo Persada.

Peter Jones and Paul Merricks, 1999, The management of Food Service Operation : Cassel Wellington house, London.

Rymbertus A Amakora Andrikus, 2000. Pelaksanaan Standar Operation Procedure di Departemen F \& B, PT. Gramedia, Jakarta. 
Tatay Sutari, Fantastic Service, Grasindo, PT. Gramedia Widiasarana Indonesia, Jakarta. 